\title{
FURTHER OBSERVATIONS ON THE UTILIZATION OF ADENOSINE TRIPHOSPHATE IN RAT MAST CELLS DURING HISTAMINE RELEASE INDUCED BY THE IONOPHORE A23187
}

\section{TORBEN JOHANSEN}

Department of Pharmacology, Odense University, J.B. Winsløws Vej 19, DK-5000 Odense C, Denmark

1 The relation between A23187-induced histamine release and the energy metabolism of the rat mast cells has been studied.

2 Ethacrynic acid was used as an inhibitor of calcium-induced histamine release from mast cells primed with the ionophore A23187, and to study calcium-induced changes in the adenosine triphosphate (ATP) content and the rate of lactate production of A23187-primed mast cells.

3 Ethacrynic acid by itself decreased the rate of glycolytic ATP production.

4 By measurement of the ATP content and the lactate production of mast cells with or without secretory activity, the increased demand of energy for exocytosis was estimated to be equivalent tQ 0.14 pmol of ATP per $10^{3}$ mast cells.

\section{Introduction}

The antibiotic, A23187, specifically forms complexes with calcium and magnesium and transports these ions across a variety of membranes (Reed \& Lardy, 1972). In the presence of calcium, A23187 acts as a histamine releasing agent on isolated mast cells of the rat (Foreman, Mongar \& Gomperts, 1973).

Results of a previous study of the relation between mast cell adenosine triphosphate (ATP) content and A23187-induced histamine release are consistent with the view that energy-requiring processes are involved in the release mechanism (Johansen, 1979).

The purpose of the present study was to estimate the increased cellular ATP-utilization associated with the exocytotic process of A23187-induced histamine release. The estimation is based on measurement of the cellular ATP content and the rate of lactate production as a measure of the cellular ATP-synthesis. The experiments were performed with mast cells with only glycolytic ATP-synthesis supported by exogenous glucose, as the respiratory ATP-synthesis was blocked by treatment of the cells with respiratory inhibitors. Ethacrynic acid inhibits histamine release induced by the ionophore A23187 in the presence of calcium (Chakravarty, 1979). Ethacrynic acid was used in order to study calcium-induced changes in the ATP content and the rate of lactate production of A23187-primed mast cells and their relation to histamine release.

\section{Methods}

Isolation of rat mast cells

Male Sprague-Dawley rats, 340 to $560 \mathrm{~g}$, were used for the experiments. Mast cells were isolated as described previously (Johansen, 1979). The mast cell fraction consisted of $97.1 \% \pm 0.5 \%$ (mean \pm s.e. mean, $n=27$ ) mast cells.

\section{Incubation procedure}

Mast cell suspensions pooled from one to eight rats were divided into aliquots with the same cell density in a final volume of $0.5 \mathrm{ml}$. These were used for determination of the ATP content, the lactate production of the mast cells, and for the histamine release experiments. The cell density in different experiments for histamine release and ATP determination varied from $0.82 \times 10^{5}$ to $1.80 \times 10^{5}$ cells per ml. For the lactate experiments the cell density. was $5.8 \times 10^{5}$ to $6.6 \times 10^{5}$ cells per $\mathrm{ml}$. The cell suspensions were equilibrated in a $37^{\circ} \mathrm{C}$ bath for $10 \mathrm{~min}$ in a calcium-free Krebs-Ringer solution, and then a reagent mixture was added. The reagent mixture consisted of antimycin A $(1 \mu \mathrm{mol} / \mathrm{l})$, oligomycin $(1 \mu \mathrm{g} / \mathrm{ml})$. A23187 (10 $\mu \mathrm{mol} / \mathrm{l})$ and glucose $(1 \mathrm{mmol} / \mathrm{l})$ without or with ethacrynic acid $(0.5 \mathrm{mmol} / \mathrm{l})$. After $20 \mathrm{~min}$ incubation with the reagent mixture, calcium $(1 \mathrm{mmol} / \mathrm{l})$ was added to the cell suspension. In separate experiments 
in calcium-free Krebs-Ringer solution the effect of the reagent mixture with ethacrynic acid on the ATP content of the mast cells was studied. Samples for determination of control values of the ATP content of the cells in the presence and absence of the reagent mixture or glucose were included. Samples for determination of A23187-induced histamine release and for determination of calcium-induced histamine release from A23187-primed cells as well as samples for spontaneous histamine release were also included. Histamine release induced by A23187 from mast cells suspended in calcium containing Krebs-Ringer solution was induced by exposure of the mast cells to A23187 for $10 \mathrm{~min}$. When the cells were pretreated with A23187 (for at least $10 \mathrm{~min}$ ), the time of exposure of the cells to calcium was $5 \mathrm{~min}$ or more, which was sufficient for the release process to be completed (Johansen, 1978).

\section{Determination of lactate production}

After the incubation period, the reaction was stopped by quickly adding chilled perchloric acid (PCA) to the cell suspension giving a final PCA-concentration of $330 \mathrm{mmol} / \mathrm{l}$. Immediately after this the centrifuge tubes were placed on the whirl mixer and thereafter kept in an ice-bath for 10 to $20 \mathrm{~min}$. They were then centrifuged for $10 \mathrm{~min}$ at $1800 \mathrm{~g}$ at 2 to $3^{\circ} \mathrm{C}$ and the supernatant neutralized with a chilled mixture of $\mathrm{KOH}$ solution and 2-amino-2-methyl-propanol buffer to give a final $\mathrm{pH} 9.8$ to 10.0 . The samples were kept at $-85^{\circ} \mathrm{C}$ until tested for the lactate content, usually within a week. Internal standards and blanks were carried through the whole procedure, omitting the incubation at $37^{\circ} \mathrm{C}$. The internal standards consisted of mast cells, reagent mixture (respiratory inhibitors, A23187, glucose with or without ethacrynic acid), and lactate standard.

Lactate was measured according to the method described by Lowry \& Passonneau (1972): $500 \mu \mathrm{l}$ standards, blanks or samples were added to tubes containing $491 \mu \mathrm{l}$ of a reagent solution containing $\mathrm{NAD}^{+}(600 \mu \mathrm{mol} / \mathrm{l})$, glutamate $(2.5 \mathrm{mmol} / \mathrm{l})$ and glutamic-pyruvic transaminase $(5 \mathrm{u})$ in 2-amino-2methyl-propanol buffer $(100 \mathrm{mmol} / \mathrm{l}, \mathrm{pH} 9.9)$, and the reaction was started by adding beef heart lactic dehydrogenase $(11 \mathrm{u})$ to the tubes, giving a final volume of $1.0 \mathrm{ml}$. The amount of lactate in the samples was expressed as pmol lactate per $10^{3}$ mast cells.

Determination of histamine release and the ATP content of the mast cells

The histamine release experiments were performed as described previously (Johansen \& Chakravarty, 1975). Histamine release was determined by the fluorometric method (Shore, Burkhalter \& Cohn, 1959) including the extraction procedure with butanol and heptane. The release of histamine was calculated as a percentage of the total histamine content of the mast cells. For the determination of ATP, the reaction after incubation of the samples was stopped by chilled PCA. After neutralization of the supernatant, the ATP content was determined by the bioluminescence technique using luciferin-luciferase from firefly tails as described earlier (Johansen \& Chakravarty, 1975). No interference with the ATP determination by any of the reagents occurred.

\section{Materials}

Human serum albumin was supplied by $A B$ KABI (Stockholm, Sweden), antimycin A, oligomycin, L-lactic acid, glutamic-pyruvic transaminase (porcine heart), 2-amino-2-methyl-1-propanol, and glutamate monosodium by Sigma Chemical Company (St. Louis, U.S.A.). Lactate dehydrogenase and NAD ${ }^{+}$by Boehringer-Mannheim GmbH (Mannheim, W. Germany), and glucose by BDH Chemicals Ltd. All other chemicals were of analytical grade. Ethacrynic acid was dissolved in $0.9 \% \mathrm{w} / \mathrm{v} \mathrm{NaCl}$ solution (saline) at $\mathrm{pH} 11$ to 12. After neutralization the final $\mathrm{pH}$ in Krebs-Ringer solution with human serum albumin, $1 \mathrm{mg} / \mathrm{ml}$, was 7.0 to 7.1 .

The Krebs-Ringer solution had the following composition (mmol/l): $\mathrm{NaCl} 143.3, \mathrm{KCl} 4.7, \mathrm{MgSO}_{4} 1.2$, $\mathrm{Na}_{2} \mathrm{HPO}_{4}$ 2.5, $\mathrm{KH}_{2} \mathrm{PO}_{4}$ 0.6. In the presence of calcium $2.54 \mathrm{mmol} / \mathrm{l}$ (Figure 1), $\mathrm{NaCl}$ was reduced to $139.8 \mathrm{mmol} / \mathrm{l}$.

\section{Results}

\section{Inhibition of histamine release by ethacrynic acid}

Figure 1 shows the results of exposure of the mast cells to increasing concentrations of ethacrynic acid during the $10 \mathrm{~min}$ of temperature equilibration on A23187-induced histamine release. As the concentration of ethacrynic acid increased from $0.1 \mathrm{mmol} / \mathrm{l}$, a gradual increase in inhibition of A23187-induced histamine release was found. Histamine release was completely blocked by ethacrynic acid $0.5 \mathrm{mmol} / \mathrm{l}$.

Calcium-induced changes in cellular ATP content and its relation to histamine release

In these experiments the mast cells were pretreated with A23187 in calcium-free Krebs-Ringer solution, and the histamine release was initiated by adding calcium to the cell suspension. The respiratory chain was blocked by antimycin A. Oligomycin was added to the cell suspension in addition to antimycin $A$, because these two metabolic inhibitors are known to 


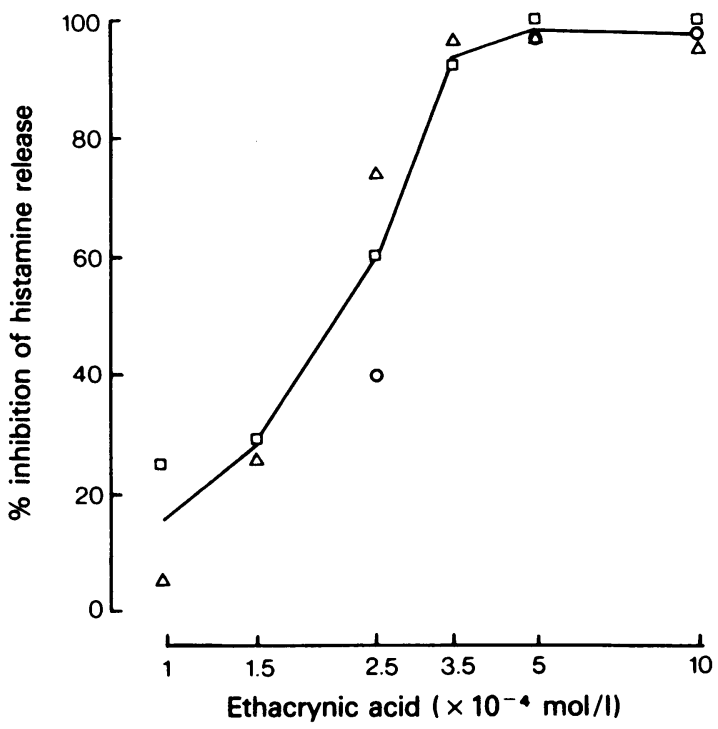

Figure 1 Inhibition of A23187-induced histamine release by ethacrynic acid. Abscissa scale: concentration of ethacrynic acid. Ordinate scale: inhibition of histamine release. Zero value on the ordinate scale represents the histamine release from control samples incubated without ethacrynic acid: $80.0 \%$ (mean value). Spontaneous histamine release (mean $3.9 \%$ ) deducted. No difference in spontaneous histamine release in the presence and absence of ethacrynic acid $(1 \mathrm{mmol} / \mathrm{l})$ was observed. Individual results from 3 experiments.

block the energy-dependent calcium uptake by suspensions of isolated mitochondria (Vasington \& Murphy, 1962; Rossi \& Lehninger, 1963; Brierley, Murer \& Green, 1963; Brierley; Murer \& Bachmann, 1964; Bielawski \& Lehninger, 1966). Glucose was used as a substrate for the glycolysis. Histamine release (mean $51 \%$ ) was completed after 2 min incubation with calcium, and $85 \%$ of the release occurred within the first min. After 1 and 2 min incubation there was a decrease in the ATP content of the mast cells of 37 and $60 \%$, respectively (Figure 2). This was followed by a further decrease of $22 \%$ after $5 \mathrm{~min}$ incubation. In control experiments without calcium (not shown in the figure), incubation of the cells with A23187, respiratory inhibitors and glucose for 10 to $30 \mathrm{~min}$ resulted in a steady state level of cellular ATP of 44 to $46 \%$ of the normal ATP value from cells incubated with glucose alone. This was followed by a small decrease in ATP to a level of $38 \%$ after $60 \mathrm{~min}$ incubation. In similar experiments with ethacrynic acid there was a $21 \%$ decrease in ATP after 1 min incubation of the cells with calcium. After $3 \mathrm{~min}$ incubation the decrease in ATP was $44 \%$, and no further change was

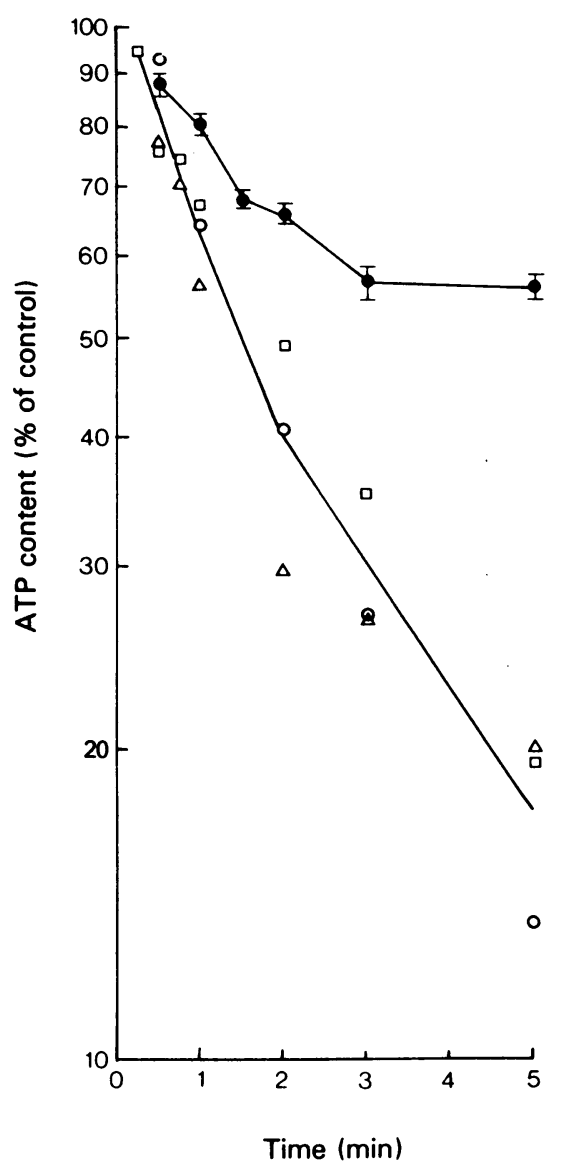

Figure 2 Changes in mast cell ATP content after incubation with calcium for $15 \mathrm{~s}$ to $5 \mathrm{~min}$ in the presence $(\bullet)$ and absence $(\square, 0, \Delta)$ of ethacrynic acid. Abscissa scale: time of incubation with calcium. Ordinate scale: ATP content as $\%$ of control value from cells incubated in calcium-free medium with respiratory inhibitors, glucose and ionophore without or with ethacrynic acid (log scale). In the absence of ethacrynic acid the control value was: $0.68 \pm 0.06 \mathrm{pmol} / 10^{3}$ cells (mean \pm s.e. mean, $n=3$ ), which was $48.7 \%$ (mean value) of the ATP content of mast cells incubated in the presence of glucose: $1.40 \pm 0.07 \mathrm{pmol} / 10^{3}$ cells (mean \pm s.e. mean, $n=3$ ). In the presence of ethacrynic acid the control value was: $0.68 \pm 0.03 \mathrm{pmol} / 10^{3}$ cells (mean \pm s.e. mean, $n=12$ ), which was $44.4 \%$ of the value from cells incubated in calcium-free Krebs-Ringer solution: $1.53 \pm 0.05 \mathrm{pmol} / 10^{3}$ cells (mean \pm s.e. mean, $n=8$ ). Figure shows results from two separate groups of experiments. Individual results from three experiments $(\square, O, \Delta)$ and mean values from 4 to 12 experiments $(\bullet)$; vertical lines show s.e. mean. The correlation coefficient between the log values of the ATP content $(0 \%$ of control) and the time of incubation of the cells with calcium is $0.977(P<0.01)$. 
observed (Figure 2). The decrease in ATP in the presence of ethacrynic acid seemed to be a first order reaction. Histamine release in the presence and absence of ethacrynic acid was 1.4 and $42.7 \%$ (mean values), respectively. Spontaneous histamine release with $(5.6 \%$ mean value) or without $(4.8 \%$ mean value $)$ ethacrynic acid was deducted. In control experiments with ethacrynic acid but without calcium, a steady state level of ATP of 46 to $49 \%$ of the normal ATP level was observed (not shown in figure). Similar experiments were performed in which the calciuminduced ATP-changes in the presence and absence of ethacrynic acid were determined in samples of the same population of mast cells (Table 1 , columns a and c). The observed value of mast cell ATP content at zero time (Table 1, columns, a and c) shows a $21 \%$ decrease of the steady state ATP level of the cells, which were dependent on glycolytic ATP-synthesis $(P<0.02$ by $t$ test). For further explanation of Table 1, see Discussion.

Lactate production by the mast cells in relation to histamine release

As shown in Figure 3 there was a linear relation between the amount of lactate produced by the mast cells and the incubation time both in the presence and absence of ethacrynic acid. In these experiments the mast cells were also treated with respiratory inhibitors (antimycin A and oligomycin), ionophore and glucose. The rate of lactate production was 1.50 $\mathrm{pmol} / 10^{3}$ cells per min in the absence of ethacrynic acid. In the presence of ethacrynic acid the rate was decreased $21 \%$, being $1.19 \mathrm{pmol} / 10^{3}$ cells per min. This part of each experiment was performed in calcium-free Krebs-Ringer solution. When calcium was added to the cell suspension after $20 \mathrm{~min}$ incuba- tion with the respiratory inhibitors, ionophore and glucose, the rate of lactate production was decreased to 1.04 and $0.79 \mathrm{pmol} / 10^{3}$ cells per min in the absence and presence of ethacrynic acid, respectively, the decrease of the rate of lactate production by calcium thus being almost the same $\left(0.46\right.$ and $0.40 \mathrm{pmol} / 10^{3}$ cells per min).

\section{Discussion}

Histamine release induced by $\mathrm{A} 23187$ in the presence of calcium seemed to be initiated by transport of calcium into the cells (Foreman et al., 1973; Johansen, 1978). In the present study mast cells were primed with A23187 and incubated with calcium in the absence or presence of ethacrynic acid, which blocked the histamine release process. After $1 \mathrm{~min}$ incubation with calcium, histamine release was almost completed and there was a considerable difference in the percentage ATP-decrease in the absence and presence of ethacrynic acid. This may be explained by an increased utilization of cellular ATP in association with the exocytotic process.

As shown in Table 1 , the value of the increased ATP-utilization was calculated as the difference (column d) between the values of a calculated curve of ATP-decrease (column $b$ ) and the observed values of the ATP-decrease (column c). The method is based on the observations that in addition to the effect of calcium on the histamine release mechanism, an inhibition of the rate of glycolytic ATP-synthesis was observed by incubation of A23187-treated cells with calcium. The inhibition was not related to the histamine release process, as almost the same inhibition of ATP-synthesis was found in the presence and absence of ethacrynic acid (Figure 3). The calculated

Table 1 Calcium-induced changes in the ATP content of ionophore A23187-primed mast cells

\begin{tabular}{|c|c|c|c|c|c|}
\hline \multirow[b]{2}{*}{$\begin{array}{l}\text { Time of incubation } \\
\text { with } \mathrm{Ca}^{2+}(\mathrm{min})\end{array}$} & \multicolumn{5}{|c|}{$A T P\left(p m o l / 10^{3}\right.$ cells $)$} \\
\hline & $\begin{array}{c}\text { With ethacrynic } \\
\text { acid } \\
\text { Mean } \pm \text { s.e. mean }\end{array}$ & $\begin{array}{c}\text { Without ethacrynic } \\
\text { acid } \\
\text { (calculated values) } \\
\text { Mean }\end{array}$ & $\begin{array}{c}\text { Without ethacrynic } \\
\text { acid } \\
\text { (observed values) } \\
\text { Mean } \pm \text { s.e. mean }\end{array}$ & $\begin{array}{l}\text { Difference } \\
\quad(b-c)\end{array}$ & $\begin{array}{c}A T P \\
\text { utilization }\end{array}$ \\
\hline 0 & $0.68 \pm 0.04(8)$ & 0.86 & $0.86 \pm 0.04(8)$ & 0 & 0 \\
\hline 1 & $0.54 \pm 0.06(3)$ & 0.73 & $0.59 \pm 0.01(3)$ & 0.14 & 0.14 \\
\hline 2 & $0.45 \pm 0.03(8)$ & 0.63 & $0.31 \pm 0.03(8)$ & 0.32 & 0.18 \\
\hline 3 & $0.36 \pm 0.03(3)$ & 0.54 & $0.28 \pm 0.02(3)$ & 0.26 & 0 \\
\hline 5 & $0.37 \pm 0.03(3)$ & 0.54 & $0.21 \pm 0.03(3)$ & 0.33 & 0 \\
\hline & (a) & (b) & (c) & (d) & (e) \\
\hline
\end{tabular}

Control value without the reagent mixture and without ethacrynic acid was $1.53 \pm 0.05(8) \mathrm{pmol} / 10^{3}$ cells (mean \pm s.e. mean). Number of experiments in parentheses. 


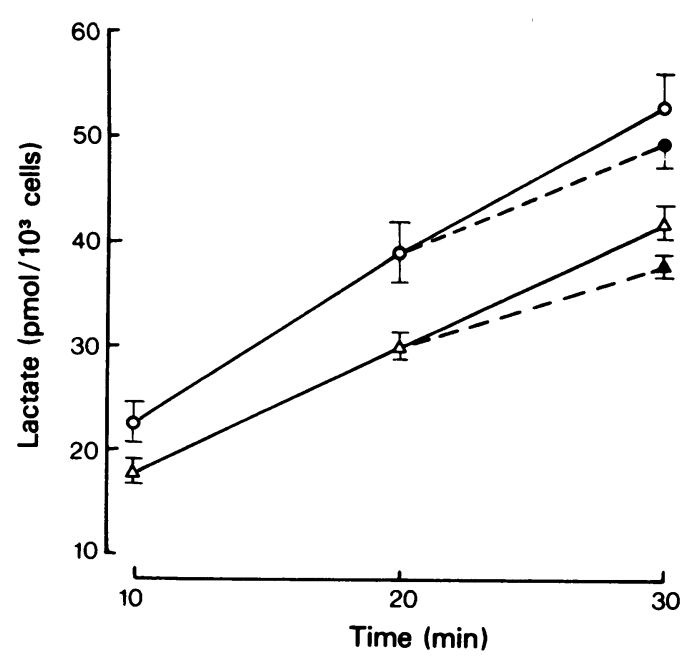

Figure 3 Lactate production by mast cells after 10 to $30 \mathrm{~min}$ incubation with respiratory inhibitors, ionophore and glucose with $(\Delta)$ or without $(0)$ ethacrynic acid. After $20 \mathrm{~min}$ incubation with the reagents, calcium was added to the cell suspension for $10 \mathrm{~min}$, which resulted in a significant decrease of the lactate production both in the presence $(\Delta)$ and absence $(O)$ of ethacrynic acid $(P<0.05$ by one-tailed $t$ test for paired data). Mean values from four $(\Delta, \Delta)$ and five $(0,0)$ experiments; vertical lines show s.e. mean.

values in Table 1 (column b) show the time course of ATP-decrease caused by the metabolic effect of calcium. The calculation is based on the assumption that the ATP-decrease is a first order reaction as is that found in the experiments with ethacrynic acid and calcium (Figure 2). The steady state ATP-level after 3 min incubation of the cells with calcium was calculated by the use of an ATP turnover time of $31 \mathrm{~s}$, which was the mean value found in the presence of ethacrynic acid with or without calcium in the medium. These values ( $28 \mathrm{~s}$ and $34 \mathrm{~s}$, respectively) were almost identical. Ethacrynic acid decreased the steady state ATP-level by an inhibition of the glycoly-

\section{References}

Bielawski, J. \& Lehninger, A.L. (1966). Stoichiometric relationship in mitochondrial accumulation of calcium and phosphate supported by hydrolysis of adenosine triphosphate. J. biol. Chem., 241, 4316-3244.

Brierley, G.P., Murer, E. \& BachmanN, E. (1964). Studies on ion transport. III. The accumulation of calcium and inorganic phosphate by heart mitochondria. Archs Biochem. Biophys., 105, 89-102.

Brierley, G.P., Murer, E. \& Green, D.E. (1963). Participation of an intermediate of oxidative phosphorylation tic ATP-synthesis since the same turnover time of ATP was found in the absence of calcium with or without ethacrynic acid (34 s).

By subtraction of the observed values (Table 1 , column c) from the calculated values (column b), it may be seen, that during the first 2 min of incubation of the cells with calcium, there was a decrease in ATP of $0.32 \mathrm{pmol} / 10^{3}$ cells without further change in the next 3 min (column d). The increased ATP-utilization in association with the histamine release was 0.14 and $0.18 \mathrm{pmol} / 10^{3}$ cells during the first and second min of incubation of the cells with calcium, respectively. Histamine release was completed after 2 min incubation with calcium. Since $85 \%$ of the total release occurred during the first min, the energy demand of the exocytotic process itself may be equivalent to $0.14 \mathrm{pmol} / 10^{3}$ cells, whereas the increased utilization of 0.18 $\mathrm{pmol} / 10^{3}$ cells during the second min is likely to be associated with recuperative and synthetic processes in the cells initiated by the cellular changes of the exocytotic process. Svendstrup \& Chakravarty (1977) observed an additional ATP-production of 0.27 $\mathrm{pmol} / 10^{3}$ cells during anaphylactic histamine release, which was of the same order of magnitude as the present findings.

The rate of glycolytic ATP-synthesis was 1.50 $\mathrm{pmol} / 10^{3}$ cells per min. Based on the respiratory rates of mast cells in presence and absence of glucose reported by Chakravarty \& Zeuthen (1965) $\left(0.47 \times 10^{-6}\right.$ and $0.29 \times 10^{-6} \mu \mathrm{l} /$ cell per $\left.\mathrm{h}\right)$, these would be responsible for a rate of ATP-synthesis of 2.10 and $1.29 \mathrm{pmol} / 10^{3}$ cells per min, assuming that glucose was the only source of energy.

I am grateful to Professor N. Chakravarty for criticism of the manuscript. The technical assistance of Mrs Annette Kragh Rasmussen and Mrs Susanne Nielsen is gratefully acknowledged. The ionophore A23187 was kindly supplied by Eli Lilly \& Co. (Indiana, U.S.A.), and ethacrynic acid by Merck-Sharp \& Dohme International (New York, U.S.A.). This work was supported by the Danish Medical Research Council, 512-15082 and by funds obtained from Novo's Foundation. in ion accumulation by mitochondria. Science, $\bar{N} . Y$., 140, 60-62.

Chakravarty, N. (1979). The metabolism of mast cells and biochemical changes associated with histamine release. In Proc. International Symp. on the Mast Cell. Its Role in Health and Disease. ed Pepys, J. Tunbridge Wells, Kent: Pitman Medical Publishing Co. Ltd.

Chakravarty, N. \& Zeuthen, E. (1965). Respiration of rat peritoneal mast cells. J. cell Biol., 25, 113-121.

Foreman, J.C., Mongar, J.L. \& Gomperts, B.D. (1973). 
Calcium ionophores and movements of calcium ions following the physiological stimulus to a secretory process. Nature, Lond., 245, 249-251.

JohanSEN, T. (1978). Mechanism of histamine release from rat mast cells induced by the ionophore A23187: effects of calcium and temperature. Br. J. Pharmac., 63, 643-649.

JOHANSEN, T. (1979). Utilization of adenosine triphosphate in rat mast cells during histamine release induced by the ionophore A23187. Br. J. Pharmac., 65, 103-109.

JohANSEN T. \& ChaKravarTy, N. (1975). The utilization of adenosine triphosphate in rat mast cells during histamine release induced by anaphylactic reaction and compound 48/80. Naunyn-Schmiedebergs Arch. Pharmac., 288, 243-260.

Lowry, O.H. \& Passonneau, J.V. (1972). A Flexible System of Enzymatic Analysis. p. 194. New York and London: Academic Press.

ReED, P.W. \& LARDY, H.A. (1972). Antibiotic A23187 as a probe for the study of calcium and magnesium function in biological systems. In The Role of Membranes in
Metabolic Regulation. ed. Mehlman, M.A. \& Hanson, R.W. pp. 111-131. New York and London: Academic Press.

Rossi, C.S. \& LeHNinger, A.L. (1963). Stoichiometric relationships between accumulation of ions by mitochondria and the energy-coupling sites in the respiratory chain. Biochem. Z., 338, 698-713.

Shore, P.A., Burkhalter, A. \& Cohn, V.H. (1959). A method for the fluorometric assay of histamine in tissues. J. Pharmac. exp. Ther., 127, 182-186.

Svendstrup, F. \& Chakravarty, N. (1977). Glucose metabolism in rat mast cells during histamine release. Expl Cell Res., 106, 223-231.

VAsington, F.D. \& MURPHY, J.V. (1962). $\mathrm{Ca}^{++}$uptake by rat kidney mitochondria and its dependence on respiration and phosphorylation. J. biol. Chem., 237, 2670-2677.

(Received July 20, 1979. Revised October 26, 1979.) 